\title{
Audit of antibiotic prophylaxis and adherence of surgeons to standard guidelines in common abdominal surgical procedures
}

Zakir Khan ${ }^{1,3}$ Naveed Ahmed, ${ }^{1}$ Shaista Zafar, ${ }^{2}$ Asim ur Rehman ${ }^{1}$, Faiz Ullah Khan ${ }^{1,4}$ Muhammad Saqlain, ${ }^{1}$ Sohail Kamran ${ }^{1}$ and Hazir Rahman ${ }^{5}$

${ }^{1}$ Department of Pharmacy, Quaid-i-Azam University, Islamabad, Pakistan (Correspondence to: Z. Khan: zakirkhank30o@gmail.com). ${ }^{2}$ Department of Surgery, Pakistan Institute of Medical Sciences, Islamabad, Pakistan. ${ }^{3}$ Institute of Health Sciences, Department of Pharmacology (Pharmacovigilance), Çukurova University, Adana, Turkey. ${ }^{4}$ Department of Pharmacy Administration and Clinical Pharmacy, School of Pharmacy, Health Science Centre,

Xi'an Jiaotong University, China. ${ }^{5}$ Department of Microbiology, Faculty of Chemical and Life Sciences, Abdul Wali Khan University, Mardan, Pakistan

\begin{abstract}
Background: Prophylactic use of antibiotics before surgery is evidence-based practice for prevention of surgical site infections (SSIs).
\end{abstract}

Aims: To investigate adherence to and surgeons' perception of antibiotic prophylaxis guidelines.

Methods: A two-phase, cross-sectional prospective study conducted in two teaching hospitals. Phase 1: 6-month audit of prescriptions to investigate adherence rate to evidence-based guidelines. The important information was collected from medical charts through a predesigned proforma. Phase 2: self-administration questionnaire was used to investigate the surgeons' perception. Descriptive statistics, independent-sample Kruskal-Wallis test and multivariate linear regression analysis were performed using SPSS version 21.0.

Results: A total of 866 eligible surgical cases (acute appendectomy; $n=418 ; 48.2 \%$ ), laparoscopic cholecystectomy $(n=278$; $32.1 \%$ ) and inguinal hernia $(n=170 ; 19.7 \%)$ were investigated. Surgical antibiotic prophylaxis was prescribed in $97.5 \%$ of procedures. Out of these, $9.5 \%$ adhered to guidelines with respect to correct choice, $40 \%$ for timing, and $100 \%$ for dose and route (optimal value $100 \%$ ). Most patients received ceftriaxone $(n=503 ; 59.5 \%)$ as prophylactic antibiotic. The questionnaire (good internal consistency; $a \geq 0.7$ ) was filled out by 200 surgeons. More than half (69\%) of participants thought that antibiotics were overused. Most surgeons perceive that poor adherence to treatment guidelines is due to poor awareness, underestimation of infection, lack of consensus, and disagreement with guidelines recommendations.

Conclusions: Surgeons have positive perception that antibiotics should be used according to guidelines recommendations. However, we found poor treatment adherence to antibiotic prophylaxis guidelines.

Keywords: abdominal surgery, adherence, antibiotic prophylaxis, surgeons' perception, treatment guidelines

Citation: Khan Z; Ahmed N; Zafar S; ur Rehman A; Ullah Khan F; Saqlain M et al. Audit of antibiotic prophylaxis and adherence of surgeons to standard guidelines in common abdominal surgical procedures. East Mediterr Health J. 2020;26(9):1052-1061. https://doi.org/10.26719/emhj.20.025

Received : 11/05/19; accepted: 18/09/19

Copyright $\odot$ World Health Organization (WHO) 2020. Open Access. Some rights reserved. This work is available under the CC BY-NC-SA 3.0 IGO

license (https://creativecommons.org/licenses/by-nc-sa/3.o/igo)

\section{Introduction}

Globally, every year > 200 million individuals undergo surgical procedures (1). About $70 \%$ of the world's population belongs to low- and middle-income countries, and most of them have surgery-associated disorders (2). Postoperative infections are a major public health concern and account for $\sim 7$ million complications around the world $(2,3)$. The most common cause of hospital-acquired infections in surgical patients is surgical site infections (SSIs), and surgical antibiotic prophylaxis (SAP) is used as standard practice to combat SSIs (4).

Per capita consumption of antibiotics is generally higher in high-income countries, but the greatest increase in antibiotic use between 2000 and 2010 was in lowincome countries, where use continues to rise, and often, heavy use of antibiotics substitutes for infection control (3). It is reported that antibiotics constitute one third of all drugs used in hospitals and $80 \%$ of antibiotics are used in surgery-associated cases (5). Appropriate use of antibiotics provides optimal benefits, when administered for an appropriate indication, with correct choice, dose, time and duration $(4,6,7)$. The antibiotic stewardship programme focuses on the appropriate use of antibiotics. Prevention of misuse, fighting against resistance, and promotion of appropriate use of antibiotics are the main goals of the stewardship programme (8). Various approaches being tried to tackle this health threat, such as understanding the factors that influence prescribing behaviour. Behaviour changes during prescribing are effective $(8,9)$.

Despite the availability of guidelines, compliance rates with appropriate selection, timing, duration and use of antibiotics in surgical procedures are low among surgeons $(6,10)$. Such practices in the healthcare system ultimately lead to increases in adverse events, antibiotic resistance, and costs of treatment $(4,6,7)$. Due to the increased use of antibiotics in surgical procedures, it is necessary to address the compliance of SAP with evidencebased guidelines and investigate the perceptions of surgeons about determinants of antibiotic use. 
The main objectives of this study were to compare current antibiotic prophylaxis practices with international standard treatment guidelines and evaluate the perception of surgeons in 2 tertiary care teaching hospitals in Islamabad, Pakistan.

\section{Methods}

\section{Phase 1: observational study phase}

\section{Study design and settings}

A 6-month prospective, observational, medical record-based study from January 1, 2017 to June 30, 2017 was conducted to investigate adherence of SAP practices with treatment guidelines. The study was conducted in national referral hospitals with 600 beds, providing medical facilities to Islamabad, Khyber Pakhtunkhwa, Azad Jammu and Kashmir, and Punjab.

\section{Sample size, sampling technique and patient characteristics}

According to the National Population Census 2017, the population of Pakistan was 207776954 and that of Islamabad 2001579 (https://www.citypopulation.de/php/pakistan-admin.php?admiid=5). The minimum obligatory sample size calculated was 601 based on $95 \%$ confidence interval and $4 \%$ margin of error using the formula $[n=N$ $\mathrm{x} /((\mathrm{N}-1) \mathrm{E} 2+\mathrm{x})]$; where $\mathrm{N}$ is the population size and $\mathrm{E}$ the margin of error. Rao soft sample size calculator was used to estimate sample size (http://www.raosoft.com/ samplesize.html).

We aimed to highlight current prescribing practice; therefore, the minimum required sample size was calculated according to the World Health Organization (WHO)/International Network of Rational Use of Drugs methodology, which states a sample size of at least 600 encounters/prescriptions of patients are required to conduct a cross-sectional prospective study describing current treatment practice (11). Rather than specifying the number of patients, a time period was selected and all the patients who underwent 1 of 3 types of surgery in that period were enrolled according to the inclusion and exclusion criteria. A universal random sampling technique was used and patients who underwent 1 of the 3 most commonly performed abdominal surgical procedures (appendectomy, laparoscopic cholecystectomy and inguinal hernia repair) were assessed during the study period. Inpatients who met the inclusion criteria during the study period were invited to participate. After explaining the purpose and nature of the study, patients gave verbal and written consent to participate. The inclusion criteria were as follows: patients who underwent the selected abdominal surgeries; age > 16 years; and no previous infection or surgery. We excluded patients who did not give their consent and those undergoing palliative care.

\section{Data collection tool}

Medical records of selected patients were obtained and the desired information was collected on a predesigned standardized data collection form (Additional File 2 ). The type of surgery, details of antibiotic prophylaxis (antibiotic agents, administration route, dosage, time), and length of hospital stay were recorded.

\section{Appropriateness and adherence to prescription guidelines}

SAP was judged as appropriate if the antibiotic, dose, route and timing were in accordance with the recommendations of international guidelines $(4,12)$. These guidelines emphasize the following aspects: (1) use of inexpensive narrow-spectrum antibiotics; (2) intravenous single dose prophylaxis; (3) administration of SAP within 1 hour before the first incision; (4) cefazolin as the first drug of choice; however, if there is allergy to beta-lactams then vancomycin or clindamycin are appropriate alternatives (metronidazole should be added against anaerobic bacteria); and (6) dose of SAP. A prescription was confirmed to be adherent to guidelines if SAP was administered as per the guidelines. All the prescriptions were evaluated against each aforementioned recommendation and adherence rate for each recommendation, that is, indication, choice, timing, route and dose, was calculated by dividing the adherent cases by total cases. A simplified scheme for reviewing the prescription of SAP to investigate adherence to the guidelines is presented in Figure 1. WHO Anatomical Therapeutic Classification was also used to report antibiotic utilization (13).

\section{Phase 2: Questionnaire-based study}

\section{Study design, and study population}

After completion of Phase 1, a 2-month prospective questionnaire-based survey was carried out to assess surgeons' perception regarding antibiotic use, guidelines adherence and other factors related to antibiotic practices. Surgeons working at the selected hospitals were recruited on a daily basis, using a simple random sampling technique, on their ward rounds by the principal investigator from July 1 to August 30, 2017. A participant information leaflet was provided to all surgeons before the study.

\section{Data collection tool}

Investigators systematically and thoroughly reviewed the available literature $(8,14)$ for development of a self-administered questionnaire (Additional File 2). The questionnaire was modified through content and face validity. The content was further validated by 2 academic experts. For modification, feasibility, and adjustment, the questionnaire was administered to a small group of 20 prescribers (10 from each hospital). After that, the recommended modifications were included in the questionnaire.

Reliability coefficients and internal consistency were measured by Cronbach's $\alpha$ in SPSS version 21.0. Cronbach's $\alpha$ was set at 0.76 . The questionnaire was divided into 2 main sections: the first included questions regarding demographic characteristics, and the second was divided into three subsections: (a) included questions regarding antibiotic use in surgical procedures; (b) included items regarding guideline adherence; and (c) included questions about the hospital pharmacist's role. 
Figure 1 Steps for reviewing the prescription of surgical antibiotic prophylaxis (SAP) to assess adherence with guidelines

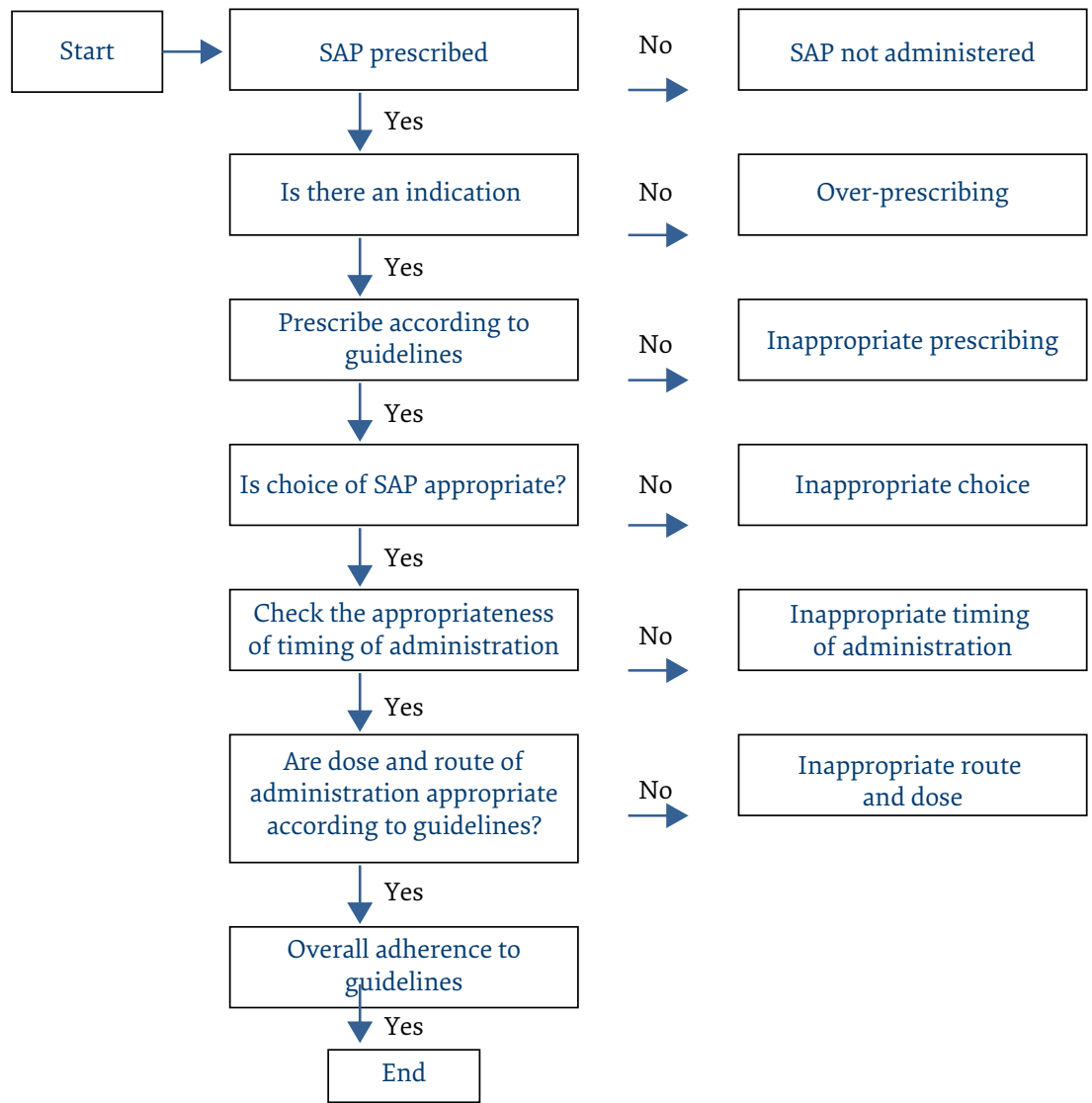

The responses were recorded on a 14-item Likert scale. Each item was scored separately as 1 (strongly disagree) to 5 (strongly agree); thus, total score ranged from 14 to 70 , with higher scores indicating more positive perception.

\section{Statistical analysis}

Descriptive statistics were calculated as frequency and percentages for categorical variables and mean and standard deviation for numerical variables. Likert scale response often provides non-normally distributed data; therefore ,independent-sample Kruskal-Wallis tests were performed to find difference in surgeons' response to each item in the questionnaire according to demographic characteristics. Multivariate linear regression analysis was performed to find factors that affected surgeons' overall perception of antibiotic guideline adherence. $\mathrm{P} \leq 0.05$ was defined as statistically significant. Statistical analysis was performed using SPSS version 22.0.

\section{Ethical approval}

The study was carried out in accordance with Declaration of Helsinki and approved by the Institutional Review Boards and Ethics Committees of Hospital A (Pakistan Institute of Medical Sciences, Islamabad, Pakistan: No. F.11/2015/ERB/SZABMU/), Hospital B (Shifa international hospital Islamabad, Pakistan: No. IRB-637-085-2016) and the Bioethical Committee of the Quaid-i-Azam University, Islamabad, Pakistan: No. DFBS/2016-623) (Additional File 3).

\section{Results}

\section{Phase 1}

\section{Pattern of surgical procedures}

A total of 1015 patients underwent common abdominal surgery. Among these, 149 (14.7\%) were excluded due to incomplete medical records $(n=62)$, having previous surgery $(n=34)$ and age $<16$ years $(n=53)$. Finally, 866 cases were recruited for the present study. Appendectomy $(n=$ $418 ; 48.2 \%$ ) was the most commonly performed operation followed by laparoscopic cholecystectomy ( $n=278 ; 32.1 \%$ ) and inguinal hernia repair $(n=170 ; 19.7 \%)$.

\section{SAP practice according to guidelines}

SAP was prescribed in 845 (97.5\%) surgical procedures (Table 1). However, appropriate antibiotics according to evidence-based guidelines were given to only 80 (9.5\%) patients. Seven hundred and sixty-five (90.5\%) patients received the wrong antibiotics with respect to guidelines, and they were not included in the calculation of the correct dose. Of the 80 patients to whom the correct antibiotic was administered, the right dose was administered in all cases. The route of administration was correct and according to recommendations. The timing of SAP was according to guidelines in $40 \%$ of patients (within 1 hour before surgical incision). 


\begin{tabular}{|c|c|c|c|c|c|}
\hline $\begin{array}{l}\text { Surgical antibiotic } \\
\text { prophylaxis practices }\end{array}$ & Appendectomy $n(\%)$ & $\begin{array}{c}\text { Laparoscopic } \\
\text { cholecystectomy } \\
\text { n (\%) }\end{array}$ & $\begin{array}{c}\text { Inguinal } \\
\text { hernia } \\
n(\%)\end{array}$ & $\begin{array}{l}\text { Total } \\
\text { n (\%) }\end{array}$ & Optimal values \\
\hline Use of antibiotics & $418(100)$ & $267(96)$ & $160(94)$ & $845(97.5)$ & $100 \%$ \\
\hline Nonuse of antibiotic & $\mathrm{o}(0)$ & $11(4)$ & $10(6)$ & $21(2.5)$ & $0 \%$ \\
\hline Antibiotic correct choice & $35(8.4)$ & $27(10.1)$ & $18(11.2)$ & $80(9.5)$ & $100 \%$ \\
\hline Correct dose & $35(100)$ & $27(100)$ & $18(100)$ & $80(100)$ & $100 \%$ \\
\hline Intravenous administration & $418(100)$ & $267(100)$ & $160(100)$ & 845 (100) & $100 \%$ \\
\hline \multicolumn{6}{|l|}{ Timing } \\
\hline 30-60 min before incision & $162(38.7)$ & $109(40.8)$ & $67(41.9)$ & $338(40)$ & $100 \%$ \\
\hline $\begin{array}{l}\text { More than } 30-60 \text { min before } \\
\text { incision }\end{array}$ & $256(61.3)$ & $158(59.2)$ & $93(58.1)$ & $507(60)$ & $100 \%$ \\
\hline
\end{tabular}

\section{Pattern of antibiotics prescribed as SAP}

Details of prescribed SAP are listed in Table 2. The most commonly prescribed class of antibiotics was cephalo- sporins. In the case of individual antibiotics, ceftriaxone was the most frequently prescribed, to 503 (59.5\%) patients.

\begin{tabular}{|c|c|c|c|}
\hline SAP (dose) & WHO/ATC code & $\begin{array}{c}\text { Hospital A } \\
\text { n (\%) }\end{array}$ & $\begin{array}{c}\text { Hospital B } \\
\text { n (\%) }\end{array}$ \\
\hline \multicolumn{4}{|c|}{ Appendectomy } \\
\hline Ceftriaxone (2 g) & Jo1XDo4 & $195(84)$ & $128(68.8)$ \\
\hline Cefoperazone+sulbactam (1g) & Jo1DD62 & $18(7.7)$ & $29(15.6)$ \\
\hline Ceftriaxone $(2 \mathrm{~g})+$ metronidazole & Jo1XD04+ Jo1XDo1 & $6(2.6)$ & $22(11.8)$ \\
\hline Ciprofloxacin (500 mg) & Jo1MA02 & $5(2.1)$ & $4(2.1)$ \\
\hline Cefazolin (2 g) & Jo1DBo4 & $4(1.7)$ & $3(1.6)$ \\
\hline Piperacillin + sulbactam (4.5 g) & Jo1CRo5 & $4(1.7)$ & - \\
\hline Total & & $232(100)$ & $186(100)$ \\
\hline \multicolumn{4}{|l|}{ Laparoscopic cholecystectomy } \\
\hline Ceftriaxone (2 g) & Jo1DDo4 & 79 (50.9) & $64(52)$ \\
\hline Cefuroxime (1.5 g) & $\mathrm{J} 01 \mathrm{DC} 02$ & $23(14.8)$ & - \\
\hline Azithromycin (500 mg) & Jo1FA10 & $19(12.2)$ & $27(21.9)$ \\
\hline Cefazolin (2 g) & Jo1DBo4 & $16(10.3)$ & $11(8.9)$ \\
\hline Amoxicillin + clavulaunic acid (1.2 g) & Jo1CRo2 & $8(5.1)$ & $7(5.7)$ \\
\hline Amikacin (500 mg) & Jo1GBo6 & $3(1.9)$ & $1(0.8)$ \\
\hline Piperacillin + sulbactam ( $4.5 \mathrm{~g})$ & Jo1CRo5 & - & $9(7.3)$ \\
\hline Nonuse of SAP & - & $7(4.5)$ & $4(3.2)$ \\
\hline Total & & $155(100)$ & $123(100)$ \\
\hline \multicolumn{4}{|l|}{ Inguinal hernia } \\
\hline Amoxicillin + clavulaunic acid (1.2 g) & Jo1CRo2 & $41(42.7)$ & $33(44.6)$ \\
\hline Cefuroxime (1.5 g) & $\mathrm{J} 01 \mathrm{DC} 02$ & $8(8.3)$ & $15(20.3)$ \\
\hline Ceftriaxone (2 g) & Jo1DDo4 & $25(26)$ & $12(16.2)$ \\
\hline Amikacin (500 mg) & Jo1GBo6 & - & $8(10.8)$ \\
\hline Cefazolin (2 g) & $\mathrm{Jo1DB04}$ & $14(14.6)$ & $4(5.4)$ \\
\hline Nonuse of SAP & - & $8(8.3)$ & $2(2.7)$ \\
\hline Total & & $96(100)$ & $74(100)$ \\
\hline
\end{tabular}

Terms in bold are drugs of choice for selected surgeries according to evidence-based guidelines. SAP = surgical antibiotic prophylaxis; WHO/ATC = World Health Organization/Anatomical Classification System. 


\section{Phase 2}

\section{Demographic characteristics of surgeons}

There were more male $(n=110 ; 55 \%)$ than female $(n=90$; $45 \%)$ prescribers. There were more respondents aged $<30$ years $(n=171 ; 85.5 \%)$ than $>30$ years $(n=29 ; 14.5 \%)$. Level of education was associate degree ( $n=93 ; 46.5 \%)$, bachelor's degree $(n=80 ; 40 \%)$ and postgraduate degree $(n=$ $27 ; 13.5 \%)$. The highest proportion of respondents had < 10 years' experience $(n=148 ; 74 \%)$ as compared to $11-20$ years $(n=48 ; 24 \%)$ and $>20$ years $(n=4 ; 2 \%)$.

\section{Surgeons' perception of antibiotic guideline adherence}

Strongly positive perceptions regarding many factors were demonstrated by all participants (Table 3). Most surgeons agreed that antibiotics are overused in surgical procedures. A total of 194 (97\%) surgeons agreed that they preferred broader-spectrum antibiotics instead of low spectrum antibiotics in a surgical procedure. One hundred and eighteen (59\%) surgeons agreed that low availa- bility of antibiotics in the hospital pharmacy affected the choice of antibiotics according to guidelines.

One hundred and twenty-eight $(64 \%)$ surgeons agreed that evidence-based guidelines should be followed before prescribing antibiotics in surgery; 186 (93\%) agreed that prescribing antibiotics without evidence-based guidelines is responsible for a high financial burden on patients; $135(67.5 \%)$ agreed that lack of consensus by surgeons about the recommendation in the guidelines is a factor for inappropriate use of antibiotics; and nonavailability of consensus local hospital guidelines was reported by 193 (96.5\%). A total of 194 (97\%) surgeons agreed about the important and crucial role of the hospital pharmacist in the development of evidence-based guidelines.

The significant relationship between sex, age, final academic degree, experience and hospital setting and all items in the questionnaire was invetigated through independent-sample Kruskal-Wallis tests analysis. Many factors were statistically significant $(P<0.05)$

Table 3 Surgeons perception regarding guidelines adherence and other determinants (Questionnaire Section 2)

\begin{tabular}{|c|c|c|c|c|c|}
\hline \multirow[t]{2}{*}{ Variables } & \multirow{2}{*}{$\begin{array}{l}\text { Strongly } \\
\text { disagree }\end{array}$} & \multicolumn{2}{|c|}{ Response, $\mathbf{n}(\%)$} & \multirow[t]{2}{*}{ Agree } & \multirow{2}{*}{$\begin{array}{l}\text { Strongly } \\
\text { agree }\end{array}$} \\
\hline & & Disagree & Uncertain & & \\
\hline \multicolumn{6}{|c|}{ Section A: Antibiotic-related items } \\
\hline Q1: Antibiotics are overused in surgical procedures? & $0(0)$ & $2(1)$ & $60(30)$ & $126(63)$ & $12(6)$ \\
\hline $\begin{array}{l}\text { Q2: Do you prefer broader-spectrum antibiotics instead } \\
\text { of low spectrum antibiotics in surgical procedure? }\end{array}$ & $2(1)$ & $1(.5)$ & $3(1.5)$ & $170(85)$ & $24(12)$ \\
\hline $\begin{array}{l}\text { Q3: Does low availability of antibiotics in the hospital } \\
\text { pharmacy affect the choice of an antibiotic according } \\
\text { to guidelines? }\end{array}$ & $1(.5)$ & $17(8.5)$ & $64(32)$ & $109(54.5)$ & $9(4.5)$ \\
\hline \multicolumn{6}{|c|}{ Section B: Guideline-adherence-related items } \\
\hline $\begin{array}{l}\text { Q4: Do you agree to prescribed antibiotic prophylaxis } \\
\text { with accurate choice, dose and timing according to } \\
\text { guidelines? }\end{array}$ & $1(.5)$ & $0(0)$ & $17(8.5)$ & $171(85.5)$ & $11(5.5)$ \\
\hline $\begin{array}{l}\text { Q5: Evidence-based guidelines should be followed } \\
\text { before prescribing antibiotics in surgery? }\end{array}$ & $\mathrm{o}(0)$ & $24(12)$ & $48(24)$ & $92(46)$ & $36(18)$ \\
\hline $\begin{array}{l}\text { Q6: Prescribing antibiotics without evidence-based } \\
\text { guidelines is responsible for a high financial burden } \\
\text { on patients? }\end{array}$ & $2(1)$ & $9(4.5)$ & $3(1.5)$ & $162(81)$ & $24(12)$ \\
\hline $\begin{array}{l}\text { Q7: Poor awareness about guidelines is a cause of } \\
\text { irrational use of antibiotics in surgery? }\end{array}$ & $1(.5)$ & $29(14.5)$ & $48(24)$ & $94(47)$ & $28(14)$ \\
\hline $\begin{array}{l}\text { Q8: Is lack of consensus by surgeons about the } \\
\text { recommendations in the guidelines a factor in } \\
\text { inappropriate use of antibiotics? }\end{array}$ & $\mathrm{o}(0)$ & $27(13.5)$ & $38(19)$ & $107(53.5)$ & $28(14)$ \\
\hline $\begin{array}{l}\text { Q9: Disagreement with guidelines is a contributing } \\
\text { factor for inappropriate use of antibiotics? }\end{array}$ & $0(0)$ & $50(25)$ & $43(21.5)$ & $92(46)$ & $15(7.5)$ \\
\hline $\begin{array}{l}\text { Q10: Underestimation of infection rate is a factor for } \\
\text { nonadherence with guidelines? }\end{array}$ & $1(.5)$ & $1(.5)$ & $21(10.5)$ & $169(84.5)$ & $8(4)$ \\
\hline $\begin{array}{l}\text { Q11: Are guidelines good educational tools and a } \\
\text { convenient source of advice? }\end{array}$ & $0(0)$ & $14(7)$ & $29(14.5)$ & $126(63)$ & $31(15.5)$ \\
\hline Q12: I use the guidelines on a daily or weekly basis? & $0(0)$ & $3(1.5)$ & $42(21)$ & $125(62.5)$ & $30(15)$ \\
\hline $\begin{array}{l}\text { Q13: There are no available hospital-based guidelines } \\
\text { for antibiotic use in surgery? }\end{array}$ & $1(.5)$ & $0(0)$ & $6(3)$ & $167(83.5)$ & $26(13)$ \\
\hline \multicolumn{6}{|c|}{ Section C: Hospital-pharmacist-role-related item } \\
\hline $\begin{array}{l}\text { Q14: Hospital pharmacists can play an important role } \\
\text { in development of evidence-based hospital guidelines? }\end{array}$ & $\mathrm{o}(0)$ & $0(0)$ & $6(3)$ & $51(25.5)$ & $143(71.5)$ \\
\hline
\end{tabular}


(Additional File 4). Multivariate linear regression analysis was applied to find factors that affected surgeons' overall perception score (Table 4). Age, final academic degree, hospital settings and work experience were independent predictors $(P<0.05)$ of positive perception towards antibiotics use.

On comparison of findings of the 2 phases of the study (Tables 2 and 3), there was a difference between perception and prescribing behaviour of surgeons toward evidence-based prescribing. Assessment of prescriptions showed poor adherence to treatment guidelines, while most surgeons had a positive perception toward rational prescribing as per guideline recommendations.

\section{Discussion}

The current study focused on assessment of adherence to and surgeons' perceptions of SAP guidelines. We observed a substantial proportion of inappropriate SAP practices with evidence-based standard treatment guidelines. Findings revealed poor compliance to treatment guidelines, with only $9.5 \%(n=80)$ of patients receiving $\mathrm{SAP}$ as per guidelines. These findings are consistent with other studies conducted in Italy (15) and Brazil (16), which reported adherence rate of $5.7 \%$ and $3-5.8 \%$, respectively. However, in contrast, higher adherence rates were reported in Qatar (68\%) (17), India 52\% (18) and Philippines (44\%) (19). To ensure appropriate use of SAP, the first step is to provide educational training with an antibiotic stewardship programme and awareness regarding its importance. Previous studies have demonstrated the benefits of educational intervention for appropriate antibiotic prophylaxis. Studies in Nigeria (10) and Italy (15) found that compliance with antibiotic prophylaxis guidelines improved with increased awareness among surgeons and other healthcare team members.

Appropriate timing of administration of SAP was $40 \%(n=338)$ in our study. Mixed results were found in the literature. The current findings are comparable with studies in the Philippines and Australia $(19,20)$. Studies in Northern Nigeria (16.5\%) (10) and Egypt (5\%) (21) reported lower adherence rates, whereas higher adherence rates were reported in Jordan (99\%) (22), France (76.6\%) (23) and Palestine $(60 \%)(24)$. This is evidence that delayed administration of SAP is associated with a 2 times greater risk of SSIs as compared to timely administration (10). Appropriate time of administration of SAP could also reduce the duration of stay and hospitalization cost $(4,12)$.
A possible explanation of the poor adherence rate in the present study is nonavailability of standard guidelines and protocols for antibiotic prophylaxis in these hospitals $(10,25)$. Lack of knowledge, unavailability of clinical pharmacists and poor collaboration with healthcare teams are other possible reasons for noncompliance. Further, large scale and multicentre studies are needed to identify other contributing factors to noncompliance.

The most commonly prescribed SAP was ceftriaxone, which was administered to $503(59.5 \%)$ cases. In line with our findings, studies in Ethiopia (6) and Turkey (26) also reported that ceftriaxone was excessively and inappropriately used in their settings. Antibiotics should be cost-effective, nontoxic and with a limited spectrum (4, 24). Cefazolin is sufficient to cover pathogens involved in SSI. Inappropriate use of antibiotics provides a favourable environment for microbial resistance and increases the possibility of adverse reactions $(4,12)$. However, we observed a low level of cefazolin use in our study, which is in line with studies in the Islamic Republic of Iran (27) and Saudi Arabia (28). These findings revealed that the surgical team is not keeping up to date with standards of best practice.

The second phase of our study aimed to assess surgeons' perception regarding antibiotic prescribing according to standard guidelines in surgical wards in Pakistani hospitals. Most of the respondents perceived that overuse of antibiotics, preference of broad-spectrum antibiotics and nonavailability of antibiotics were the main problems in surgical wards. Similar findings are also reported in other studies worldwide $(8,14,18)$. Studies in Malaysia and India reported that surgeons perceived that broad-spectrum antibiotics with long duration are more effective than narrow-spectrum antibiotics $(14,18)$. These findings are important to address because overuse, broad-spectrum antibiotics, and nonavailability problems have a potential impact on patient care and infection control activities.

The importance of evidence-based treatment guidelines cannot be denied. Prescribers scored highly for the guideline adherence items in the current study, which suggests a general acceptance of evidence-based guidelines. Guideline adherence scores were similar to other studies conducted in the United Kingdom of Great Britain and Northern Ireland (8) and France (29). This reflects a positive attitude and preference of prescribers towards guidelines. Standard treatment guidelines are crucial for rational use of therapy. Updated and evidence-

\begin{tabular}{|c|c|c|c|c|}
\hline Variables & $\boldsymbol{\beta}$ & Standard error & $t$ & $\mathbf{P}$ \\
\hline Age & -3.439 & 0.987 & -3.484 & 0.001 \\
\hline Sex & 0.559 & 0.593 & 0.943 & 0.347 \\
\hline Final academic degree & 1.410 & 0.476 & 2.962 & 0.003 \\
\hline Work experience & 1.904 & 0.760 & 2.505 & 0.013 \\
\hline Hospital setting & -2.688 & 0.581 & -4.625 & 0.000 \\
\hline
\end{tabular}

Bold values shown significant factors. 
based guidelines should be provided to prescribers that ultimately enhance effective and quicker appropriate use of antibiotics (30). Most of the participants in our study reported that they used guidelines on a daily basis but also reported nonavailability of hospital-based local guidelines. Similar results were reported in the Philippines (31). Although positive attitudes towards guidelines were shown in our study they had a limited impact on practice. However, the reasons behind nonadherence to guidelines in our study may be lack of awareness of appropriate guidelines, lack of consensus by the surgeons with the guidelines, ineffective distribution system for the latest version of guidelines, and lack of regular educational training sessions (14).

The current findings of alarmingly low adherence rates to treatment guidelines imply that serious practical measures should be taken by hospital administrators and policy-makers to improve prescribing practice. Poor prescribing practice results in poor treatment outcomes and serious consequences such as higher incidence of adverse reactions, waste of resources and increased treatment costs. Most surgeons perceived that local hospital-based treatment guidelines are a prerequisite to improve prescribing practice and ultimately patient care. Also, measures should be taken to fill the gap between prescribers' perception and practice. Pharmacists could play a vital role in the development of evidence-based hospital guidelines and antibiotic stewardship programmes (32-34). Most of the participants in our study agreed about the important role of hospital pharmacists in the development of guidelines. However, in our setting, the pharmacists' role was mainly confined to dispensing drugs and not development of guidelines and decision-making. There is an urgent need for policies to be implemented by governments, hospital administrations and clinical teams of surgeons to acknowledge and support the vital role of hospital pharmacists. Prolonged working time, decreased workload and increased numbers of hospital pharmacists may be important strategies to monitor antibiotic use and development of guidelines for surgical patients. Such interventions are the key to success of antimicrobial stewardship programmes (33).

The current study had access to well-reported data on SAP and was adequately powered; however, some limitations must be acknowledged. First, the present study only focused on compliance rate of SAP in 3 common surgical procedures. Second, we used published recommendations of evidence-based international guidelines to measure against the appropriate use of SAP in selected operations because there were no local consensus guidelines available in both hospitals. However, the possibility exists that recommendations given by the guidelines were not practicable in our patients or for the situation in Pakistan. Third, the study did not monitor postoperative infection rate. Therefore, we do not know if nonadherence to the guidelines had any clinical consequences. Moreover, the questionnaire was only distributed to 2 tertiary care hospitals in Islamabad. Therefore, these findings cannot be generalized for the whole country. However, these findings do add useful information, particularly around appropriate antibiotic use, adherence to standard guidelines, perception of surgeons, and factors that affect antibiotic prescribing in surgery and health systems in developing countries.

\section{Conclusions}

Our findings indicates poor adherence to evidenced-based guidelines for administration of SAP. Surgeons have positive perception that antibiotics should be used according to guideline recommendations. Most surgeons perceive that poor adherence to treatment guidelines is due to poor awareness, underestimation of infection, lack of consensus and disagreement with guideline recommendations. The results provide evidence that healthcare providers should be aware of their larger role in reducing inappropriate antibiotic prescription prior to surgery. Good prescribing practices are crucial for patient safety and better health outcomes, although prescribers still rely on their own personal experiences while prescribing therapeutic agents. Compliance with guidelines by surgeons remains a challenge, as reported by previous studies worldwide and in the present study. Nonadherence with guidelines may have increased antibiotic resistance and healthcare-associated infection rates. Real actions are urgently needed for the implementation of guidelines and to address the related factors of such practices. Continuous educational training, availability of appropriate antimicrobials, and implementation of local and international treatment guidelines and antimicrobial stewardship programmes are required for appropriate utilization of SAP. Furthermore, our findings suggest that large-scale multicentre studies should be conducted to evaluate the factors that affect antibiotic prescribing across the provinces of Pakistan.

\section{Acknowledgement}

We would like to thank the administration of both hospitals for their help and cooperation during data collection.

Funding: None.

Competing interests: None declared. 


\section{Audit de l'antibioprophylaxie et de l'observance des lignes directrices standard par les chirurgiens dans les actes courants de chirurgie abdominale}

\section{Résumé}

Contexte : L'usage prophylactique des antibiotiques préalablement à un acte chirurgical est une pratique fondée sur des données probantes, qui permet de prévenir les infections du site opératoire (ISO).

Objectifs : Étudier l'observance des lignes directrices en matière d'antibioprophylaxie et le point de vue des chirurgiens sur cette pratique.

Méthodes : Une étude prospective transversale en deux phases, a été menée dans deux hôpitaux universitaires. Phase 1: Audit des ordonnances sur six mois, afin d'évaluer le taux de d'observance des lignes directrices fondées sur des données probantes. Les informations importantes ont été recueillies à partir des dossiers médicaux au moyen d'un formulaire conçu à cet effet. Phase 2 : un auto-questionnaire a été utilisé pour étudier le point de vue des chirurgiens. Des statistiques descriptives ont été produites, un test de Kruskal-Wallis sur échantillons indépendants et une analyse de régression linéaire multivariée ont été réalisés à l'aide du logiciel SPPS, version 21.0.

Résultats : Au total, 866 cas chirurgicaux répondant aux critères de l'étude ont été examinés : appendicectomies aiguës, ( $n=418$, soit 48,2 \%), cholécystectomies laparoscopiques, $(n=278$, soit $32,1 \%$ ) et hernies inguinales ( $n=170$, soit $19,7 \%$ ). Une antibioprophylaxie chirurgicale a été prescrite dans 97,5\% des interventions. Parmi ces dernières, le respect des lignes directrices était de 9,5\% pour le choix de l'antibiotique, de $40 \%$ pour le moment de l'administration et de $100 \%$ pour la dose et la voie d'administration, la valeur optimale étant $100 \%$. La majorité des patients ont reçu de la ceftriaxone $(n=503$, soit 59,5\%) comme antibiotique prophylactique. Le questionnaire a été rempli par 200 chirurgiens, avec une cohérence interne satisfaisante $(\alpha \geq 0,7)$. Plus de la moitié (69\%) des participants estimaient que les antibiotiques étaient surutilisés. La majorité des chirurgiens pensent que l'observance médiocre des lignes directrices de traitement est due à un manque de sensibilisation, à une sous-estimation de l'infection, à l'absence d'un consensus et à un désaccord avec les recommandations de ces lignes directrices.

Conclusions : Les chirurgiens approuvent l'usage des antibiotiques conformément aux recommandations des lignes directrices de traitement. Cependant, notre étude révèle une observance médiocre de ces textes dans les traitements d'antibioprophylaxie.

$$
\begin{aligned}
& \text { مر اجعة استعال المضادات الحيوية الوقائية ومدى امتثال الجحر احين للمبادئ التوجيهية القياسية في الإجر اءات المبات }
\end{aligned}
$$

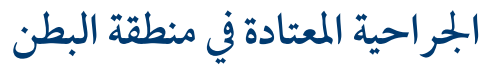

$$
\begin{aligned}
& \text { ذاكر خان، نافيد أحمد، شايستا ظفار، عاصم الرحمن، فايز الله خان، محمد صقلان، سُهيل قامران، حاضر رحمن. }
\end{aligned}
$$

الخلفية: يُعتبر استعال المضادات الحيوية على سبيل الوقاية قبل الجر احة من الملمارسات المُسنَدة بالبيّنات للوقاية من حدوث عدوى المو اضع الجر احية. الأهداف: هدفت هذه الدراسة إلى تحرّي مدى الامتثال للمبادئ التوجيهية الخاصة باستعمال المضادات الحيوية الوقائية ومنظور الجر احين في هذا

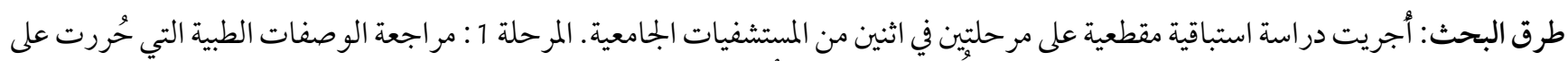

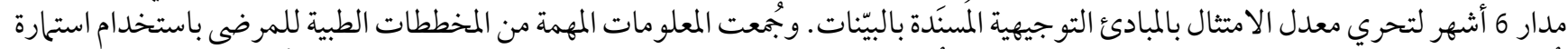

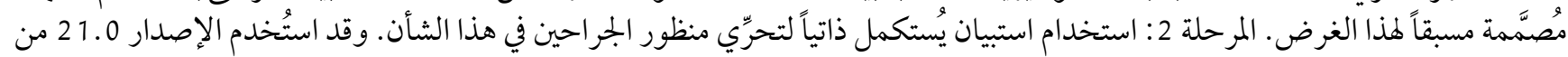

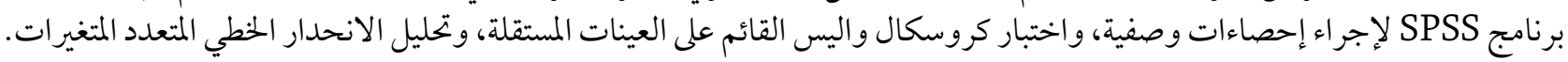
النتائج: بلغ بجموع الحالات الجر احية التي تصلح للخضوع لهذه الدراسة 866 العالِ 86 حالة، تراوحت بين استئصال الزائدة الدودية الملتهبة التهاباً حاداً

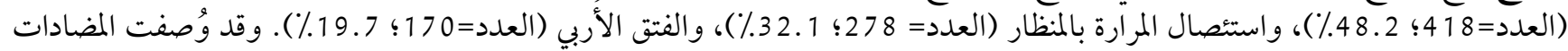

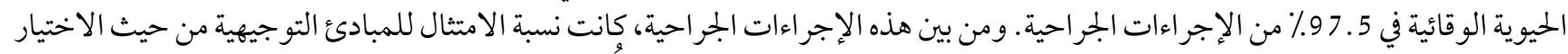

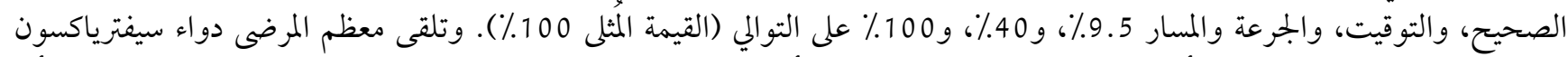

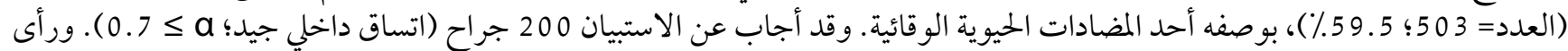

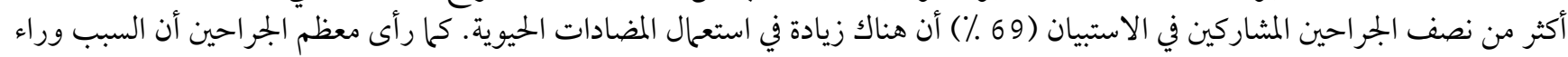

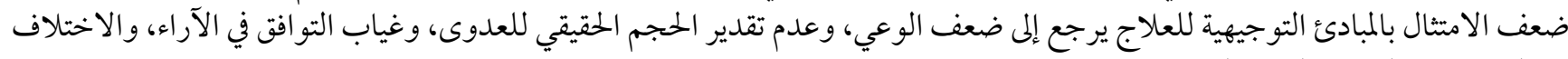
مع التوصيات الخاصة بالمبادئ التوجيهية. بالمبادئ.

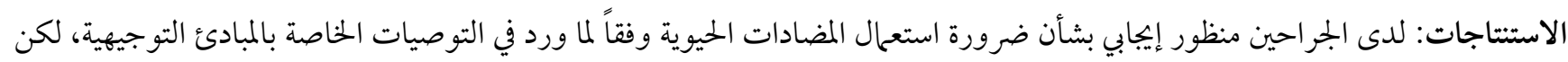

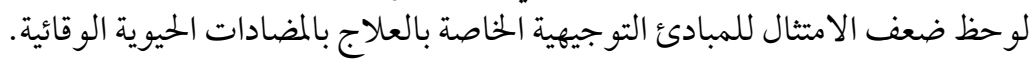




\section{References}

1. Zafar SN, McQueen KK. Surgery, public health, and Pakistan. World J Surg. 2011;35(12):2625-34. http://dx.doi.org/10.1007/soo268011-1304-3 PMID:21964819

2. Weiser TG, Regenbogen SE, Thompson KD, Haynes AB, Lipsitz SR, Berry WR, et al. An estimation of the global volume of surgery: a modelling strategy based on available data. Lancet. 2008;372(9633):139-44. http://dx.doi.org/10.1016/So140-6736(08)60878-8 PMID:18582931

3. The state of the world's antibiotics 2015. Center for Disease Dynamics, Economics \& Policy; 2015.

4. Bratzler DW, Dellinger EP, Olsen KM, Perl TM, Auwaerter PG, Bolon MK, et al. Clinical practice guidelines for antimicrobial prophylaxis in surgery. Am J Health Syst Pharm. 2013 Feb 1;70(3):195-283. doi: 10.2146/ajhp12056 PMID:23327981

5. Hansen S, Sohr D, Piening B, Pena Diaz L, Gropmann A, Leistner R, et al. Antibiotic usage in German hospitals: results of the second national prevalence study. J Antimicrob Chemother. 2013 Dec;68(12):2934-9. http://dx.doi.org/10.1093/jac/dkt292 PMID:23873646

6. Alemkere G. Antibiotic usage in surgical prophylaxis: a prospective observational study in the surgical ward of Nekemte referral hospital. PloS One. 2018 Sep 13;13(9):e0203523. http://dx.doi.org/10.1371/journal.pone.0203523 PMID:30212477

7. Khan Z, Ahmed N, Rehman AU, Khan FU, Karataş Y. Utilization pattern of antibiotics and patient care indicators in the teaching hospitals, Islamabad, Pakistan. SN Comprehens Clin Med. 2019;1:812-6. https://doi.org/10.1007/s42399-019-00131-z.

8. Parker HM, Mattick K. The determinants of antimicrobial prescribing among hospital doctors in England: a framework to inform tailored stewardship interventions. British journal of clinical pharmacology. 2016 Aug;82(2):431-40. http;//dx.doi. org/10.1111/bcp.12953 PMID:27038778

9. Davey P, Brown E, Charani E, Fenelon L, Gould IM, Holmes A, et al. Interventions to improve antibiotic prescribing practices for hospital inpatients. Cochrane Database Syst Rev. 2017 Feb 9;2:CDo03543. http://dx.doi.org/10.1002/14651858.CDoo3543.pub4 PMID:28178770

10. Abubakar U, Sulaiman SS, Adesiyun A. Utilization of surgical antibiotic prophylaxis for obstetrics and gynaecology surgeries in Northern Nigeria. Inte J Clin Pharm. 2018;40(5):1037-43. http://dx.doi.org/10.1007/s11096-018-0702-o PMID:30054786

11. Lwanga SK, Lemeshow S. Sample size determination in health studies: a practical manual. Geneva: World Health Organization; 1991 (https://apps.who.int/iris/handle/10665/40062, accessed 10 March 2020).

12. Ban KA, Minei JP, Laronga C, Harbrecht BG, Jensen EH, Fry DE, et al. American College of Surgeons and Surgical Infection Society: surgical site infection guidelines, 2016 update. J Am Coll Surg. 2017 Jan;224(1):59-74. http://dx.doi.org/10.1016/j.jamcollsurg.2016.10.029 PMID:27915053

13. ATC/DDD methodology [website]. World Health Organization; 2018 (https://www.who.int/medicines/regulation/medicines/ safety/toolkit_methodology/en/,accessed 10 December 2018).

14. Ng RS, Chong CP. Surgeons' adherence to guidelines for surgical antimicrobial prophylaxis - a review. Australas Med J. 2012;5(10):534-40. http://dx.doi.org/10.4066/AMJ.2012.1312 PMID:23173017

15. Giordano M, Squillace L, Pavia M. Appropriateness of surgical antibiotic prophylaxis in pediatric patients in Italy. Infect Control Hosp Epidemiol. 2017;38(7):823-31. http://dx.doi.org/10.1017/ice.2017.79 PMID:28580893

16. Schmitt C, Lacerda RA, Padoveze MC, Turrini RNT. Applying validated quality indicators to surgical antibiotic prophylaxis in a Brazilian hospital: learning what should be learned. Am J Infect Control. 2012 Dec;40(10):960-2. http://dx.doi.org/10.1016/j. ajic.2012.01.016 PMID:22622512

17. Tourmousoglou C, Yiannakopoulou EC, Kalapothaki V, Bramis J, Papadopoulos JS. Adherence to guidelines for antibiotic prophylaxis in general surgery: a critical appraisal. J Antimicrob Chemother. 2007 Jan;61(1):214-8. http://dx.doi.org/10.1093/jac/dkm406 PMID:17999981

18. Parulekar L, Soman R, Singhal T, Rodrigues C, Dastur F, Mehta A. How good is compliance with surgical antibiotic prophylaxis guidelines in a tertiary care private hospital in India? A prospective study. Indian J Surg. 2009 Feb;71(1):15-8. http://dx.doi. org/10.1007/s12262-009-0004-9 PMID:23133102

19. Nabor MIP, Buckley BS, Lapitan MCM. Compliance with international guidelines on antibiotic prophylaxis for elective surgeries at a tertiary-level hospital in the Philippines. Healthcare Infection. 2015 Sep-Dec;20(3-4):145-51. https://doi.org/10.1071/ HI15018

20. Jaber S, Rogers C, Sunderland B, Parsons R, MacKenzie S, Seet J, et al. Appropriateness of surgical antibiotic prophylaxis for breast surgery procedures. Int J Clin Pharm. 2017 Apr;39(2):483-6. http://dx.doi.org/10.1007/s11096-017-0434-6 PMID:28205064

21. Saied T, Hafez SF, Kandeel A, El-Kholy A, Ismail G, Aboushady M, et al. Antimicrobial stewardship to optimize the use of antimicrobials for surgical prophylaxis in Egypt: A multicenter pilot intervention study. Am J infect Control. 2015 Nov;43(11):e67-71. http://dx.doi.org/10.1016/j.ajic.2015.07.004 PMID:26315059

22. Al-Momany NH, Al-Bakri AG, Makahleh ZM, Wazaify MM. Adherence to international antimicrobial prophylaxis guidelines in cardiac surgery: a Jordanian study demonstrates need for quality improvement. J Managed Care Pharm. 2009 Apr;15(3):262-71. http://dx.doi.org/10.18553/jmcp.2009.15.3.262 PMID:19326957 
23. Miliani K, L'hériteau F, Astagneau P, Group INS. Non-compliance with recommendations for the practice of antibiotic prophylaxis and risk of surgical site infection: results of a multilevel analysis from the INCISO Surveillance Network. J Antimicrob Chemother. 2009 Dec;64(6):1307-15. http://dx.doi.org/10.1093/jac/dkp367 PMID:19837713

24. Musmar SM, Baba H. Adherence to guidelines of antibiotic prophylactic use in surgery: a prospective cohort study in North West Bank, Palestine. BMC Surg. 2014 Sep 9;14(1):69. http://dx.doi.org/10.1186/1471-2482-14-69 PMID:25204205

25. Ayele Y, Taye H. Antibiotic utilization pattern for surgical site infection prophylaxis at Dil Chora Referral Hospital Surgical Ward, Dire Dawa, Eastern Ethiopia. BMC Res Notes. 2018;11(1):537. https://doi.org/10.1186/s13104-018-3629-6

26. Erbay A, Çolpan A, Bodur H, Çevik MA, Samore MH, Ergönül Ö. Evaluation of antibiotic use in a hospital with an antibiotic restriction policy. Int J Antimicrob Agents. 2003 Apr;21(4):308-12. http://dx.doi.org/10.1016/s0924-8579(02)00392-8 PMID:12672575

27. Nabovati E, Vakili-Arki H, Taherzadeh Z, Hasibian MR, Abu-Hanna A, Eslami S. Drug-drug interactions in inpatient and outpatient settings in Iran: a systematic review of the literature. Daru. 2014 Jun 25;22(1):52. http://dx.doi.org/10.1186/2008-2231-22-52 PMID:24965959

28. Mohajer KA, Al-Yami SM, Al-Jeraisy MI, Abolfotouh MA. Antibiotic prescribing in a pediatric emergency setting in central Saudi Arabia. Saudi Med J. 2011 Feb;32(2):197-8. PMID:21301771

29. Pulcini C, Williams F, Molinari N, Davey P, Nathwani D. Junior doctors' knowledge and perceptions of antibiotic resistance and prescribing: a survey in France and Scotland. Clin Microbiol Infect. 2011 Jan;17(1):80-7. http://dx.doi.org/10.1111/j.14690691.2010.03179.x PMID:20132254

30. Amabile-Cuevas C. Antibiotic resistance in Mexico: a brief overview of the current status and its causes. J Infect Dev Ctries. 2010 Mar 29;4(3):126-31. http://dx.doi.org/10.3855/jidc.427 PMID:20351451

31. Matti PRA, Querol RC, Antonio-Velmonte M, de Vera RL, Alejandria M. Prescribing practices of surgeons and factors that limit adherence to the Philippine College of Surgeons Clinical Practice Guidelines on antimicrobial prophylaxis for elective surgical procedures at the UP-PGH surgical wards. Philipp J Microbiol Infect Dis. 2002;31(3):107-24. http://www.herdin.ph/index.php/ herdin-home?view=research\&cid=35136

32. Zhang H-X, Li X, Huo H-Q, Liang P, Zhang J-P, Ge W-H. Pharmacist interventions for prophylactic antibiotic use in urological inpatients undergoing clean or clean-contaminated operations in a Chinese hospital. PloS One. 2014 Feb 25;9(2):e88971. http:// dx.doi.org/10.1371/journal.pone.0088971 PMID:24586465

33. Brink AJ, Messina AP, Feldman C, Richards GA, van den Bergh D, Alliance NASS. From guidelines to practice: a pharmacist-driven prospective audit and feedback improvement model for peri-operative antibiotic prophylaxis in 34 South African hospitals. J Antimicrob Chemother. 2016 Apr 1;72(4):1227-34. http://dx.doi.org/10.1093/jac/dkw523 PMID:27999061

34. Weller T, Jamieson C. The expanding role of the antibiotic pharmacist. J Antimicrob Chemother. 2004 Sep;54(2):295-8. http:// dx.doi.org/10.1093/jac/dkh327 